Ambiente \& Água - An Interdisciplinary Journal of Applied Science
ISSN 1980-993X - doi:10.4136/1980-993X
www.ambi-agua.net
E-mail: ambi.agua@gmail.com

\title{
Elimination of chemical oxygen demand from domestic residual water by electrocoagulation with aluminum and iron electrodes
}

ARTICLES doi:10.4136/ambi-agua.2240

Received: 09 Feb. 2018; Accepted: 27 Aug. 2018

\section{Edwar Alejandro Aguilar Ascón}

\author{
Universidad de Lima, Lima, Peru \\ Instituto de Investigación Científica (IDIC). E-mail: eaguilaa@ulima.edu.pe
}

\begin{abstract}
This research determined the efficiency of removal of chemical oxygen demand (COD) by an electrocoagulation process. An electrocoagulation reactor with aluminum and iron electrodes was used to treat water from the treatment plant of the Research Center for Wastewater Treatment and Hazardous Waste. The COD removal percentage was a response variable for the experimental factorial design. The factors influencing the process were current intensity, treatment time, and $\mathrm{pH}$. The best results in the percentage of removal of the COD were very similar to that obtained at a $\mathrm{pH}$ of 8.2 and 7 , with values of $83 \%$ and $84 \%$, respectively, with a current intensity of $7 \mathrm{~A}$ and a treatment time of $15 \mathrm{~min}$. However, at $5 \mathrm{~A}$ and $10 \mathrm{~min}$, values that exceed $80 \%$ removal were obtained. Statistical analysis indicates that only current intensity and time were significant for the response variable. Electrocoagulation is a viable process for the treatment of this type of effluent, in addition to being more versatile compared with biological processes.
\end{abstract}

Keywords: aluminum electrode, COD, iron electrode, urban wastewaters.

\section{Eliminação da demanda química de oxigênio da água residual doméstica por eletrocoagulação com eletrodos de alumínio e ferro}

\section{RESUMO}

O objetivo desta pesquisa foi identificar a eficiência do processo de eletrocoagulação para a remoção da demanda química de oxigênio (DQO). Foi utilizada água da estação de tratamento do Centro de Pesquisas de Tratamento de Águas Residuais e Resíduos Perigosos, empregando um reator de eletrocoagulação cujos eletrodos são feitos de alumínio e ferro. O desenho experimental fatorial teve como variável de resposta a porcentagem de remoção da DQO e como fatores que influenciam o processo a intensidade da corrente, o tempo de tratamento e o $\mathrm{pH}$. Os melhores resultados relacionados à porcentagem de remoção da DQO foram muito semelhantes a um $\mathrm{pH}$ de 8,2 e 7 , com valores respectivos de $83 \%$ e $84 \%$, uma intensidade de corrente de 7 amperes e um tempo de tratamento de 15 minutos. Entretanto, utilizando uma intensidade de 5 amperes e um tempo de tratamento de 10 minutos, os valores obtidos superam $80 \%$ de remoção. A análise estatística indica que somente a intensidade da corrente e o tempo foram significativos para a variável de resposta. A eletrocoagulação é um processo viável para o tratamento deste tipo de efluentes, além de ser mais versátil do que os processos biológicos.

Palavras-chave: águas residuais urbanas, DQO, eletrodo de alumínio, eletrodo de ferro. 


\section{INTRODUCTION}

A large amount of wastewater is generated in Peru, mainly comprised of physiological waste from domestic and commercial human activity. According to the Agency of Environmental Evaluation and Control (OEFA), approximately 2,217,946 $\mathrm{m}^{3}$ of wastewater is generated per day in Peru, which is discharged into the public sewer system, wherein only $32 \%$ of the entire volume is treated. Only a fraction of the treated water is used to irrigate crops, green areas, or for fish farming.

These effluents are generally treated by biological processes (including activated sludge and stabilization ponds), which are based on the use of microorganisms for the degradation of organic matter and the removal of pollutants. The activated sludge is among the most efficient conventional processes, which achieves high percentages of chemical oxygen demand (COD) removal and biochemical oxygen demand (BOD). However, this technology is very sensitive to parameters such as organic load, $\mathrm{pH}$, dissolved oxygen, and presence of toxic compounds. In addition, supplying oxygen to biomass is required in this process, and its retention times are prolonged, which increases operational and maintenance costs.

Electrocoagulation is used to decontaminate various types of residual water; therefore, various studies have been conducted to better understand the mechanics of electrocoagulation. In 2013, Bazrafshan et al. (2013) investigated the effects of voltage, reaction time, and spacing between the plates during electrocoagulation in residual water that was obtained from the lactic industry using aluminum electrodes, which resulted in a COD elimination of $98.84 \%$ at $60 \mathrm{~V}$ for a period of $60 \mathrm{~min}$. In 2013, Al-Shannag et al. (2013) used the electrocoagulation technique with residual municipal water to improve the reduction of COD and obtained $86.0 \%$ and 89.10\% COD elimination without and with aeration, respectively. In the subsequent year, AlShannag et al. (2014) applied this process to reduce the COD of residual waters obtained from a bakery using iron electrodes, which evaluated the $\mathrm{pH}$ parameters and the density of the current, and obtained an elimination of up to 85\% COD with an energy consumption of $0.493 \mathrm{kWh}$. In 2017, Bani-Melhem et al. (2017) demonstrated the impact of the SCOD fraction with the total elimination of COD using $\mathrm{Al}$ and Fe electrodes to eliminate $96 \%$ of the total COD and $10 \%$ of the SCOD for 15 minutes of the electrocoagulation duration.

Additionally, in recent years, there have been efforts to improve the efficiency of elimination of COD and other containments using processes that combine electrocoagulation and chemical coagulation. In 2012, Bazrafshan (2012a; 2012b) applied this to the residual waters from a slaughterhouse and obtained an elimination of 99\% DBO by adding $100 \mathrm{mg}$ of chemical coagulants using aluminum electrodes and by applying 40 volts. In the same year, this process was applied to the residual waters from a car wash using polyaluminum chlorine and aluminum electrodes, which resulted in an elimination of 96.87\% of COD. In 2015, Bazrafshan et al. (2015) also applied this process to the residual water from the textile industry and reported a $98 \%$ elimination of COD.

There are a few specific studies that have applied electrocoagulation to either domestic or municipal residual water. In 2008, Ugur Kurt (Kurt et al., 2008) used an electrolysis cell to remove COD and suspended solids and obtained efficiencies of $60 \%$ and $70 \%$, respectively. In 2009, Fuat Ozyonar (Ozyonar and Karagozoglu, 2011) conducted tests in which they obtained $72 \%$ elimination of COD with aluminum electrodes at a natural $\mathrm{pH}$ of 7.8 and a treatment time of $10 \mathrm{~min}$.

The work by Sarala (2012) can also be cited, who evaluated the effect of iron electrodes in the removal of domestic wastewater, thereby obtaining a 90\% removal of COD in a contact time of $20 \mathrm{~min}$ and at a current intensity of 0.36 A. Further, in 2012, Moreno et al. (2013) treated the residual municipal waters to eliminate COD and obtained efficiencies of elimination that varied from $77 \%$ to $94 \%$ using iron electrodes. 
In another study in 2015, Nagarajappa used copper and aluminum electrodes at different time intervals, $\mathrm{pH}$, and voltage values to treat this type of effluent. Chemical demand for oxygen and nitrates were among the main parameters evaluated, with removal percentages of $63.2 \%$ and 62\%, respectively. Another study was completed by Lech Smoczyńskia in 2017, who used aluminum electrodes in residual municipal water and achieved COD elimination of up to $63.5 \%$. In recent years, the treatment of different types of wastewater using the electrocoagulation process has attracted considerable attention, increasing the amount of literature published on the subject (Kuokkanen et al., 2013).

In general, the electrocoagulation process is used to treat wastewater originating from industries. There are very few studies on the treatment of domestic wastewater; therefore, it is important to conduct studies with real effluents monitored on site and taking into account that the wastewater features may vary according to the country. This will allow us to obtain data to evaluate the feasibility of this process instead of the biological processes.

Considering the above-mentioned issue and to find alternatives for the treatment of domestic wastewater, the main objectives of this study were to determine the efficiency of the electrocoagulation process in the removal of COD and to study the impact of the main operational parameters on the alternative process. The results will allow us to verify what is indicated by the references on this process, which is a more versatile technology and less sensitive to the parameters that affect conventional water treatment processes.

Electrocoagulation is a complex process wherein various chemical and physical phenomena are involved and consumable electrodes such as iron and aluminum are supplied with electric current to release ions to the wastewater flow (Mollah et al., 2004). An electrocoagulation reactor is an electrochemical cell in which a sacrificial aluminum or iron electrode as the anode is dissolved; this dissolved electrode doses the coagulating agent in contaminated water (Holt et al., 2005). These ions serve as destabilizing agents for the emulsion by neutralizing the strengths of repulsion that are maintained by the suspended particles in an aqueous medium, which causes the agglomeration of the colloidal particles. (Al-Qodah et al., 2018). (See Figure 1). These agglomerates with a neutral load will either float or fall depending on their density. For example, if aluminum is used in an anode, aluminum cations will be produced $\left(\mathrm{Al}^{+3}\right)$, and aluminum will act as a coagulant agent that can be used in traditional treatment systems for residual waters. This process exhibits several advantages with respect to another treatment process that includes reduction of the production of mud, which makes the operation easier, and does not include the addition of chemical products.

At the same time, electrolytic gases (typically hydrogen) are generated at the cathode (Holt et al., 2005). The electrocoagulation reactors can be of a batch-type or continuous system reactors (Mollah et al., 2004). These types of reactors depend on the volume and features of the pollutants present in wastewater to be treated. The batch-type reactor can only treat a certain volume in a treatment cycle (Restrepo et al., 2006).

According to the literature, there are factors that significantly influence the efficiency of the electrocoagulation process, including $\mathrm{pH}$, conductivity, current density, and time of electrolysis for batch processes and flow velocity for continuous processes (Restrepo et al., 2006). These parameters will be described in more detail later.

The most commonly used materials for electrodes are aluminum and iron. Herein, we present their reactions according to Chen (2004) and Piña et al. (2011).

At the anode:

$A l-3 e \rightarrow A l^{3+}$

In alkaline conditions:

$\mathrm{Al}^{+3}+3 \mathrm{OH} \rightarrow \mathrm{Al}(\mathrm{OH})_{3}$ 
In acidic conditions:

$\mathrm{Al}^{+3}+3 \mathrm{H}_{2} \mathrm{O} \rightarrow \mathrm{Al}(\mathrm{OH})_{3}+3 \mathrm{H}^{+}$

For iron anode:

$\mathrm{Fe}-2 e \rightarrow \mathrm{Fe}^{2+}$

In alkaline conditions:

$\mathrm{Fe}^{2+}+2 \mathrm{OH}^{-} \rightarrow \mathrm{Fe}(\mathrm{OH})_{2}$

In acidic conditions:

$4 \mathrm{Fe}^{2+}+\mathrm{O}_{2}+2 \mathrm{H}_{2} \mathrm{O} \rightarrow 4 \mathrm{Fe}^{3+}+4 \mathrm{OH}^{-}$

The electrolysis of water produces oxygen and hydrogen in the following way:

At the anode:

$2 \mathrm{H}_{2} \mathrm{O}-4 e \rightarrow \mathrm{O}_{2}+4 \mathrm{H}^{+}$

At the cathode it is:

$2 \mathrm{H}_{2} \mathrm{O}+2 e \rightarrow \mathrm{H}_{2}+2 \mathrm{OH}^{-}$

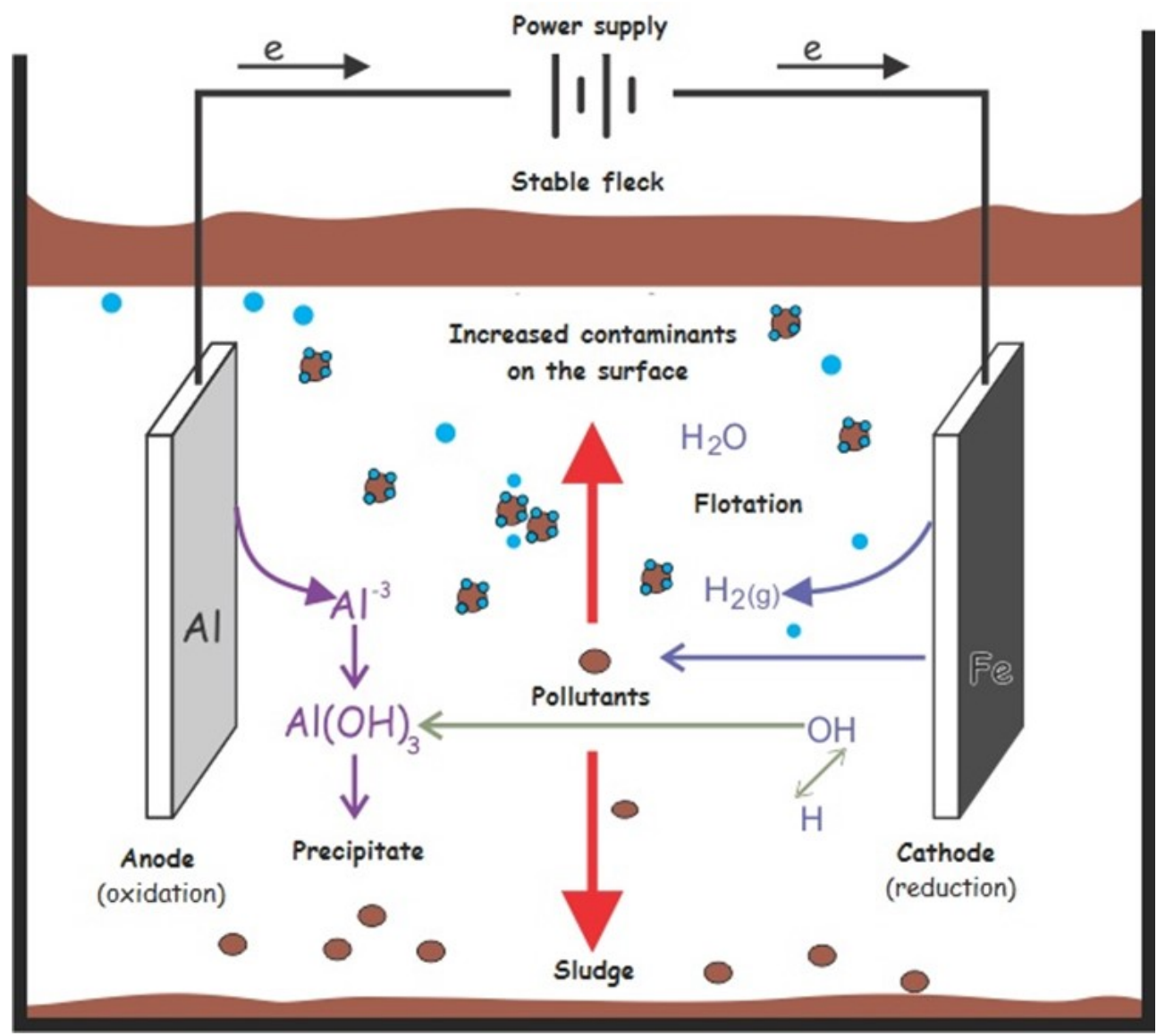

Figure 1. Interactions in the electrocoagulation process (Mollah, 2004).

The new ions of $\mathrm{Al}^{3+}$ or $\mathrm{Fe}^{2+}$ generated in the sacrificial electrodes are very efficient in the flocculation process, and they agglomerate colloidal particles. Hydrolyzed aluminum ions can form large networks of $\mathrm{Al}-\mathrm{O}-\mathrm{Al}-\mathrm{OH}$, which can remove various pollutants. Aluminum is generally used for the treatment of drinking water, and iron for wastewater treatment (Chen, 2004). 


\section{MATERIALS AND METHODS}

\subsection{Wastewater characterization}

For experimental tests, using actual wastewater taken on site was proposed because it presents totally different characteristics as compared with synthetic water used in the laboratory. The water was collected from the treatment plant located at the National College of Engineering's Research Center of Wastewater and Hazardous Waste, which has an outlet to a public network pipeline to be used in research. An initial characterization was performed to evaluate the features of this type of effluent; for the concluding tests, a considerable volume was collected in the early morning hours when there is a higher organic load.

\subsection{Electrocoagulation reactor}

The electrocoagulation reactor is designed to work in a batch type system with the capacity to treat $6.0 \mathrm{l}$ of domestic wastewater and has a footprint size of $15 \times 20 \times 22 \mathrm{~cm}$, with a free space for the accumulation of sludge. The material used for the reactor was made of a transparent acrylic material and was completely removable, which helps in observing the reactions during the process and for a better cleaning after each treatment. The supports on the bases allowed spacing to be adjusted between the plates of the electrodes. Four aluminum electrodes were used at the anode and four iron electrodes at the cathode, which were $10 \mathrm{~cm}$ wide, $10 \mathrm{~cm}$ long, and $0.01 \mathrm{~cm}$ thick, with an area of $100 \mathrm{~cm}^{2}$. The power source had the capacity to supply from 0 to 12 A with an adjustable voltage from 0 to $32 \mathrm{~V}$. A plastic tap was installed at the lower part of the reactor to obtain the samples at regular time intervals (See Figure 2).

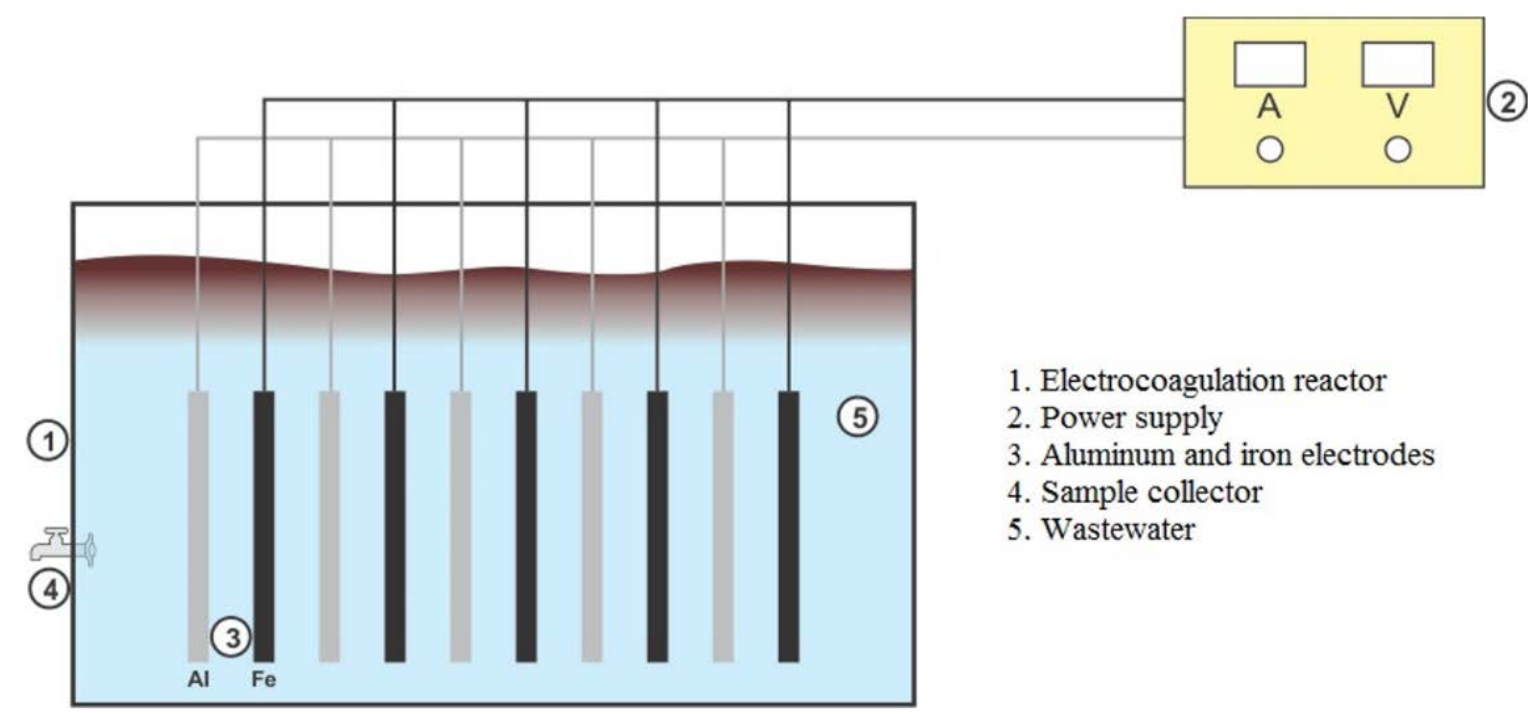

Figure 2. Diagram of the electrocoagulation reactor.

\subsection{Experimental tests}

Once the volume of water for the final tests had been taken, a sample was drawn to obtain the initial COD value of the wastewater to be treated. During the first stage, tests were conducted with an effluent at its natural $\mathrm{pH}$ of 8.2; the current intensities (3, 5, and $7 \mathrm{~A}$ ) were adjusted and samples were obtained at different times $(5,10$, and $15 \mathrm{~min}$ ) with each current intensity. During the second stage, the $\mathrm{pH}$ of its initial state was adjusted to 7 to verify how it influences the process. This is because several authors indicate that the best percentages of pollutant removal are obtained at $\mathrm{pH}$ values close to neutral. Conductivity, $\mathrm{pH}$, and temperature measurements were conducted on site with an OAKTON PCS 35 multi parameter, whereas the COD analyses were performed at the laboratory based on the SMEWW method APHA- 
AWWA-WEF 5220-D, 22nd Ed. 2012 COD Closed Reflux Method. Equation 1 was used to determine the COD removal percentage values.

$\% R=\frac{C O D i-C O D f}{C O D i} x 100$

Where:

$\%$ : COD removal percentage

$D Q O_{i}:$ Initial COD concentration $(\mathrm{mg} / \mathrm{L})$

$D Q O_{f}:$ Final COD concentration $(\mathrm{mg} / \mathrm{L})$

\subsection{Experimental design}

In this study, a factorial design with several levels was used. The efficiency of electrocoagulation is mostly influenced by the density of the current or voltage, the treatment time, the $\mathrm{pH}$ of the residual water, the conductivity, and the temperature (Piña et al., 2011; AlQodah and Al-Shannag, 2017); however, in case of a study related to the residual water that was obtained from a plant, not all these factors were considered due to the difficulty of handling them. Therefore, the factors that were considered in this design were the intensity of the current (A), time (B), and $\mathrm{pH}(\mathrm{C})$ along the variability of the results that were obtained in the percentage of elimination of COD (y).This allowed us to determine the individual effect and the interaction between the factors on the response variable and their significance in the process. All statistical analyses were performed using the Statgraphics Centurion XVI software. With these results, the analysis of variance (ANOVA) Table 1 with a confidence level of 95\%, regression coefficients of the second-order general polynomial equation, and the three-dimensional response surface graphs were obtained. Next, in Equation 2, we present the statistical model used for the analysis of the information:

$y_{i j k l}=\mu+\alpha_{i}+\beta_{j}+\gamma_{k}+(\alpha \beta)_{i j}+(\alpha \gamma)_{i k}+(\beta \gamma)_{j k}+\varepsilon_{i j k l}$

Where:

$y_{i j k l}: l-$ th observation of COD removal percentage.

$\mu:$ median COD removal percentage.

$\alpha_{i}, \beta_{j}, \gamma_{k}$ : effect of the current intensity factor, time and $p H$.

$(\alpha \beta)_{i j},(\alpha \gamma)_{i k},(\beta \gamma)_{j k}$ : effects of interaction of factors.

$\varepsilon_{i j k l}: l-$ th term of random error.

Table 1. Factors and levels in the experimental design.

\begin{tabular}{lcccc}
\multicolumn{1}{c}{ Factors } & \multicolumn{3}{c}{ Levels } \\
\hline A: Current intensity (A) & 3 & 5 & 7 \\
B: Time (min) & 5 & & 10 & 15 \\
C: pH & \multicolumn{2}{c}{7} & \multicolumn{2}{c}{8.2} \\
\hline
\end{tabular}




\section{RESULTS AND DISCUSSION}

The results of the initial characterization can be seen in Table 2, where it is observed that conductivity and $\mathrm{pH}$ have acceptable values to be used in the electrocoagulation process. In the definitive experimental tests, the initial value of the reported COD was $431 \mathrm{mg} / \mathrm{L}$ because the sample was obtained at the time of greatest organic load.

Table 2. Results of the chemical and biological physical analysis of the effluent.

\begin{tabular}{lc}
\hline Parameter & Value \\
\hline DQO (mg/L) & 347 \\
BOD $(\mathrm{mg} / \mathrm{L})$ & 182 \\
Conductivity ( $\mu \mathrm{S} / \mathrm{cm})$ & 847 \\
$\mathrm{pH}$ & 7.9 \\
Total solids (mg/L) & 74 \\
Oils and fats (UNT) & 19.2 \\
Total nitrogen (mg/L) & 39 \\
Total phosphorus (mg/L) & 4 \\
Total coliforms (NMP/100ml) & 4900000 \\
Fecal coliforms (NMP/100ml) & 2200000 \\
\hline
\end{tabular}

\subsection{Influence of retention time}

An increase in the retention time causes an increase in the consumption of energy, as well as in the consumption of the electrodes; that is why this parameter is important and must be considered since it is directly related to the economic applicability of the process (Kobya et al., 2006). Figures 3 and 4 show that after 10 min of treatment, the percentages of COD removal are similar and exceed $80 \%$, and there is no considerable variation until 15 min of treatment. Additionally, Karichappan, in 2014, indicated that the elimination efficiency of COD increases the time for electrolysis by up to $15 \mathrm{~min}$, after which the efficiency of elimination was observed to be almost constant. These results are very similar to those obtained by Bazrafshan et al. (2013), in which 75\% elimination of COD was observed 15 min into the treatment; further, an elimination of $98 \%$ was achieved 100 min into the treatment. During electrocoagulation, the concentration of the coagulant produced in the anode increased with time. Additionally, the amount of eliminated contaminant also increased with the time of electrolysis until an optimal time was reached. The optimal time is dependent on the density of the current and presents itself when the efficiency of the elimination of contaminants becomes constant.

\subsection{Influence of current intensity}

The current intensities used in the experimental part were 3, 5, and $7 \mathrm{~A}$, with a spacing of $10 \mathrm{~mm}$ between the electrodes, which was defined in previous studies and preliminary tests.

In Figures 4 and 6, it can be seen that at higher current intensity, the removal of COD is much faster after 5 min of treatment and then it becomes stable. This is similar to the findings by Merzouk et al. (2009), which indicate that the current intensity has a strong effect on the electrocoagulation process; particularly, in the kinetics of removal of pollutants, the higher the current, the shorter the treatment. This is because at high current intensity, the amount of anodic aluminum solution increases, which is favorable in view of allowing a greater amount of precipitate for the removal of pollutants. In contrast, an increase in the rate of bubble generation is observed, as well as the decrease in the size of the bubble, with the increase in intensity. All this is beneficial for the elimination of pollutants by flotation of $\mathrm{H}_{2}$ (Merzouk et al., 2009). This parameter directly determines the dose of the coagulant as well as the creation of gas bubbles. 
Therefore, it considerably influences the mixing of solutions and the transfer of mass to the electrodes (Al-Qodah end Al-Shannag, 2017). A very high value of current intensity can significantly decrease the efficiency due to the production of oxygen; moreover, it influences the passivation of the electrodes (Piña et al., 2011). It can be said that it is one of the factors that influence the electrocoagulation process the most and therefore the removal of pollutants from wastewater (Restrepo et al., 2006).

\subsection{Influence of $\mathbf{p H}$}

It is known that $\mathrm{pH}$ is an important parameter in the electrocoagulation process; optimal values thereof allow a better removal of pollutants. At a low $\mathrm{pH}$ between values of $2-3$, the cationic $\mathrm{Al}^{3+}$ and $\mathrm{Al}(\mathrm{OH})_{2}$ monomeric species predominate. When the $\mathrm{pH}$ is between 4 and 9, $\mathrm{Al}^{3+}$ and $\mathrm{OH}^{-}$ions generated by the electrodes react to form various monomeric species, such as $\mathrm{Al}(\mathrm{OH})^{2+}$ and $\mathrm{Al}(\mathrm{OH})^{22+}$, and polymeric species, such as $\mathrm{Al}_{6}(\mathrm{OH}){ }_{15}^{3+}, \mathrm{Al}_{7}(\mathrm{OH})_{17^{4+}}$, and $\mathrm{Al}_{13}(\mathrm{OH})_{34}{ }^{5+}$, that are eventually transformed into amorphous insoluble $\mathrm{Al}(\mathrm{OH})_{3(\mathrm{~s})}$ through polymerization and complex precipitation kinetics. When the $\mathrm{pH}$ is greater than 10 , the concentration of the monomeric anion of $\mathrm{Al}(\mathrm{OH})^{4-}$ increases at the expense of $\mathrm{Al}(\mathrm{OH})_{3(\mathrm{~s})}$. In addition, the cathode may be chemically attacked by $\mathrm{OH}^{-}$ions created with $\mathrm{H}_{2}$ to higher $\mathrm{pH}$ values (Merzouk et al., 2009). The nature and efficiency of the chemical reactions and complex electrochemical reactions are completely related to the $\mathrm{pH}$ of the system (Mansoorian et al., 2012).

In previous studies, it was found that the best turbidity and COD removals are obtained at $\mathrm{pH}$ values close to 7 (Restrepo et al., 2006). The effects of $\mathrm{pH}$ on water are reflected in the efficiency of the current and in the solubility of metal hydroxides (Piña et al., 2011). Keeping this in mind, the natural $\mathrm{pH}$ of the wastewater was modified to bring it to a value of 7 , and in this way, the effect of this parameter on the process was verified.

Figures 3 and 4 show the results obtained when treating water while maintaining the natural $\mathrm{pH}$ of the effluent, wherein the COD removal reached a value of $83 \%$ at a current intensity of 7 A.

The results obtained at $\mathrm{pH} 7$ can be seen in Figures 5 and 6, wherein the percentage of removal reached was $84 \%$, a value very close to that obtained at natural $\mathrm{pH}$, at an intensity of $7 \mathrm{~A}$ and a treatment time of $15 \mathrm{~min}$. These results do not match the value indicated by Piña and Restrepo, as a minimal improvement in the removal of pollutants at $\mathrm{pH}$ close to 7 was recorded. We can also highlight some coincidences with the study performed by Fuat Ozyonar (2011), in which he obtained the highest percentages of removal at a natural $\mathrm{pH}$ of 7.8 and $\mathrm{pH}$ close to neutral.

Along with these results, Al-Shannag et al. (2014) exhibited that these improved efficiencies that obtained a $\mathrm{pH}$ of 7 , or close to neutral, reported $81.7 \%$ of elimination of COD. This coincides with the observation of Bazrafshan et al. (2013), who indicated that the optimal results would obtain a $\mathrm{pH}$ of 7.24 . 


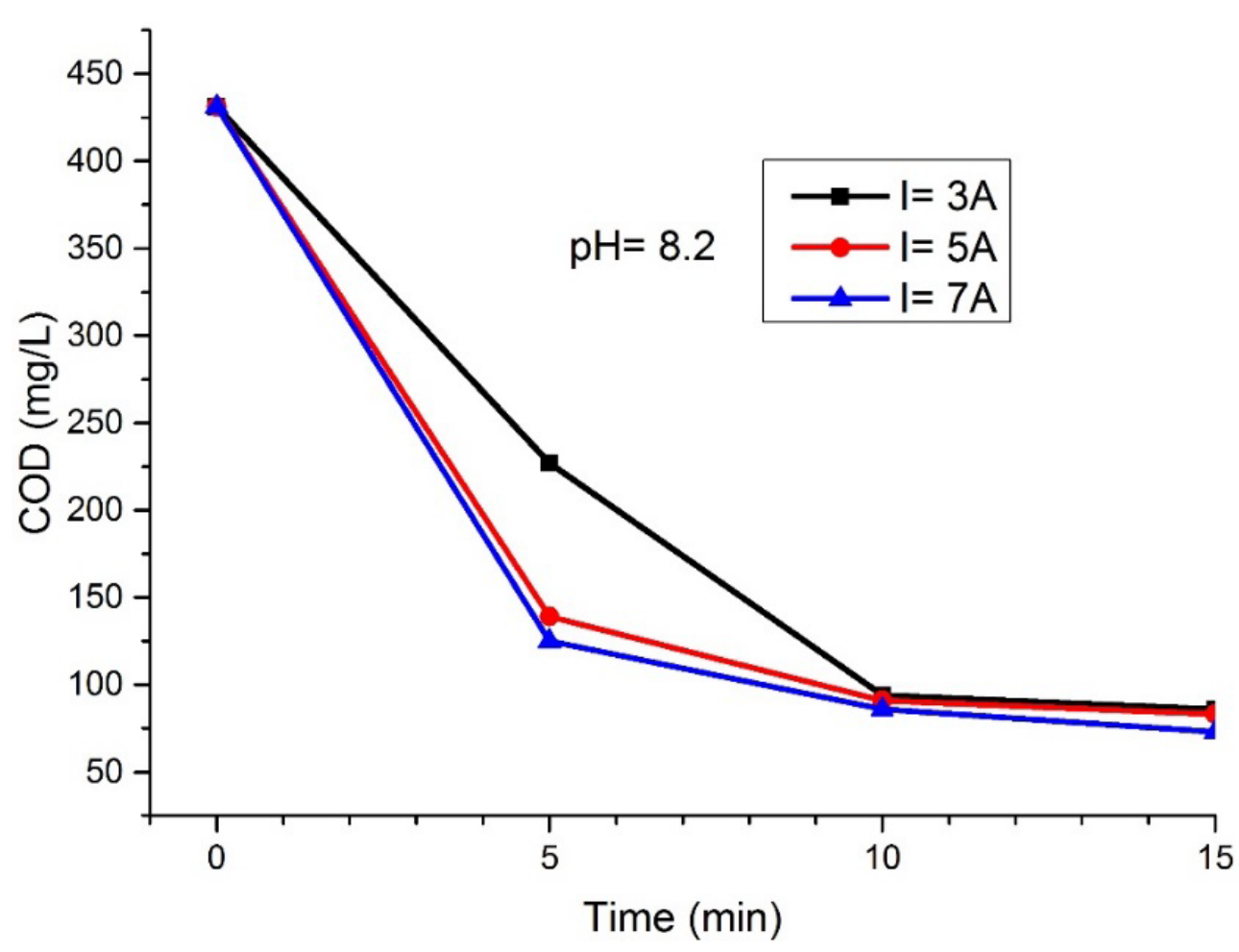

Figure 3. Variation of COD as a function of time at different current intensities $(\mathrm{COD} \mathrm{C0}=431 \mathrm{mg} / \mathrm{L}$ and $\mathrm{pH}=8.2)$.

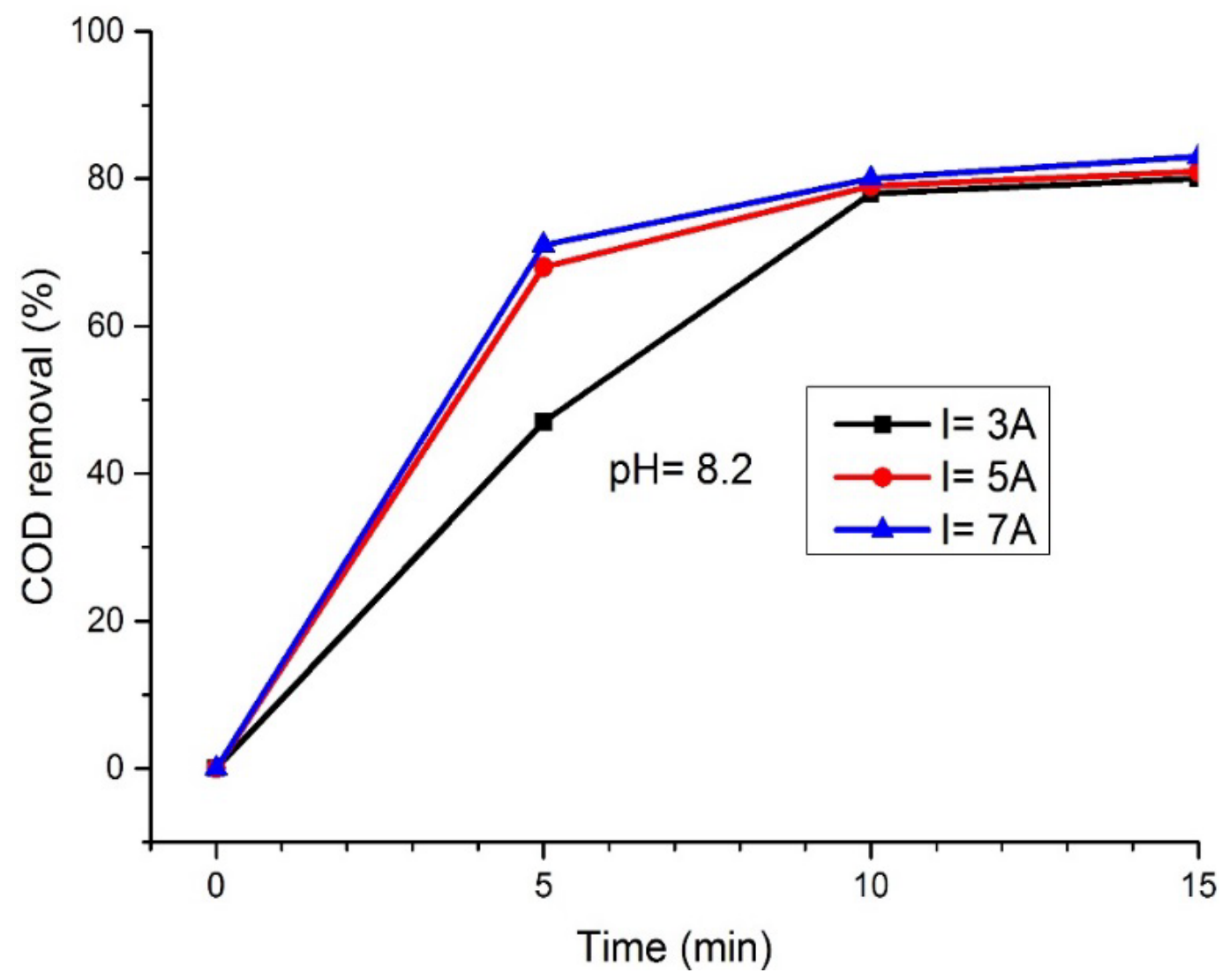

Figure 4. \% COD removal as a function of time (COD $\mathrm{C}_{0}=431 \mathrm{mg} / \mathrm{L}$ and $\mathrm{pH}=8.2$ ).

\section{IPABH}




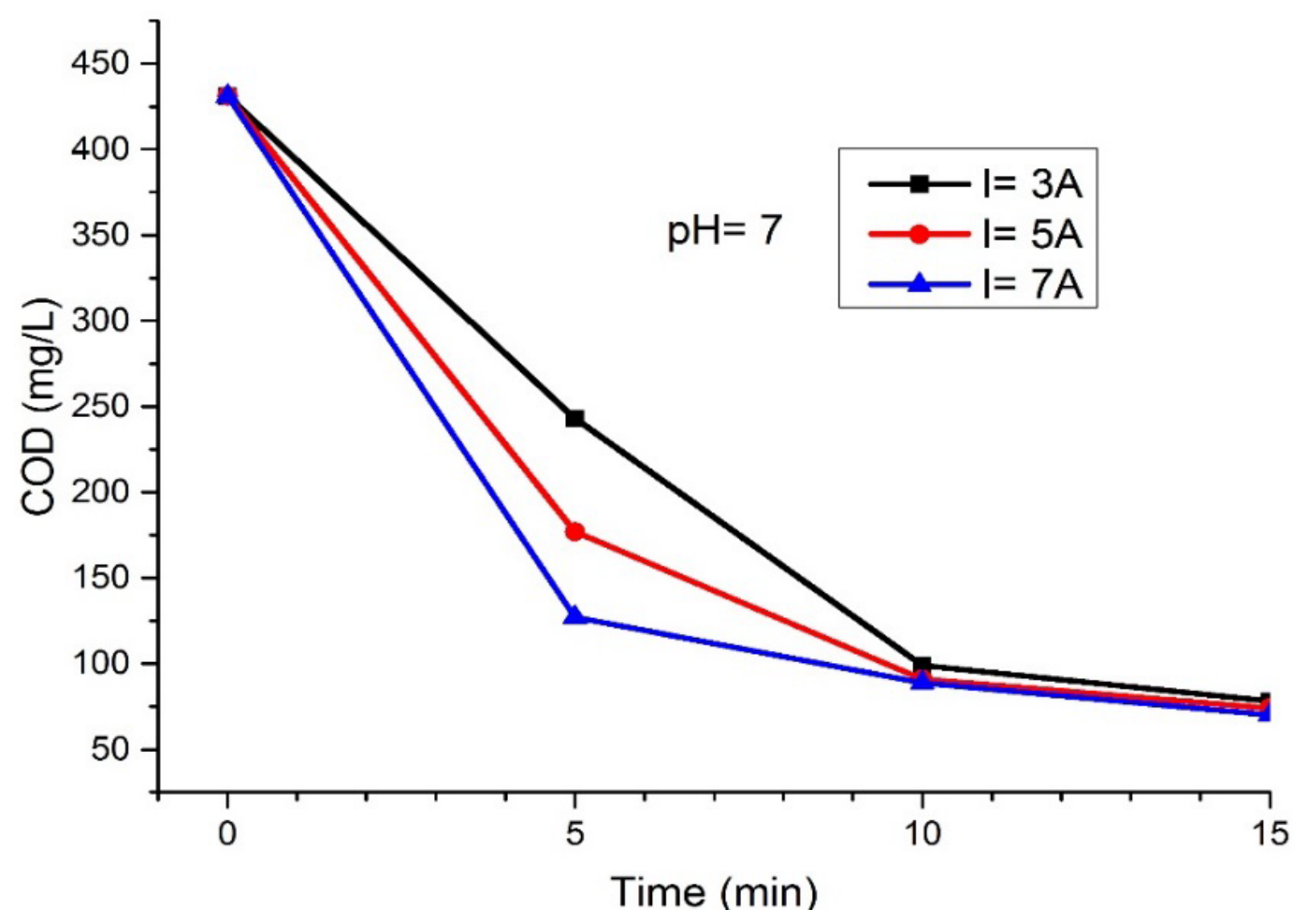

Figure 5. Variation of COD as a function of time at different current intensities (COD $\mathrm{C}_{0}=431 \mathrm{mg} / \mathrm{L}$ and $\mathrm{pH}=7$ ).

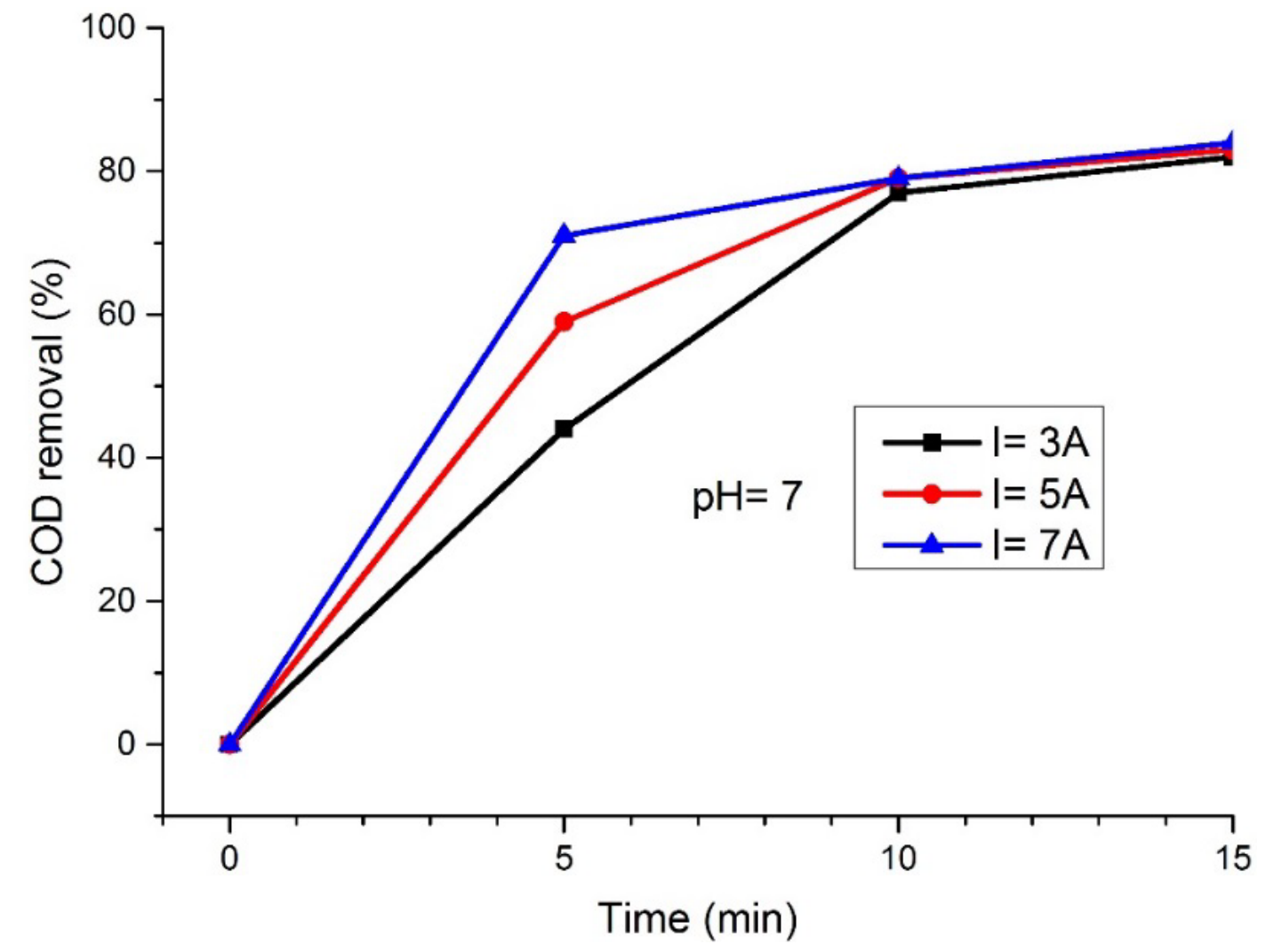

Figure 6. \% COD removal as a function of time $\left(\mathrm{COD} \mathrm{C}_{0}=431 \mathrm{mg} / \mathrm{L}\right.$ and $\left.\mathrm{pH}=7\right)$.

\subsection{Results of the experimental design}

The experimental design and the adjusted regression model that is used to quantitatively find the effects of these variables are shown in Table 3 and Equation 3. 
Table 3. Experiment design with the response variable for COD removal.

\begin{tabular}{ccccc}
\hline & \multicolumn{3}{c}{ Factors } & Removal (\%) \\
\cline { 2 - 5 } Exp. No. & Current Int. (A) & Time (min) & pH & COD \\
\cline { 2 - 5 } & A & B & C & Y \\
\hline 1 & 3 & 5 & 8.2 & 47 \\
2 & 3 & 10 & 8.2 & 78 \\
3 & 3 & 15 & 8.2 & 80 \\
4 & 3 & 5 & 7 & 44 \\
5 & 3 & 10 & 7 & 77 \\
6 & 3 & 15 & 7 & 82 \\
7 & 5 & 5 & 8.2 & 68 \\
8 & 5 & 10 & 8.2 & 79 \\
9 & 5 & 15 & 8.2 & 81 \\
10 & 5 & 5 & 7 & 59 \\
11 & 5 & 10 & 7 & 79 \\
12 & 5 & 15 & 7 & 83 \\
13 & 7 & 5 & 8.2 & 71 \\
14 & 7 & 10 & 8.2 & 80 \\
15 & 7 & 15 & 8.2 & 83 \\
16 & 7 & 5 & 7 & 71 \\
17 & 7 & 10 & 7 & 79 \\
18 & 7 & 15 & 7 & 84 \\
\hline
\end{tabular}

$Y(\%)=-72.8194+13.8889 A+14.7472 B+6.25 C-0.458333 A^{2}-0.575 A B-$

$0.138889 A C-0.303333 B^{2}-0.472222 B C$

Table 4 shows the ANOVA table, in which $\mathrm{r}^{2}$ correlation coefficient was found to be 0.9423 , which indicates that the proposed statistical model explains $94.23 \%$ of the variability of the COD removal ratio. This indicates a good fit of the model.

With respect to the significant effects of the variables, it can be determined that the effect of time and current intensity is significant at a level of $\alpha=0.05$, while $\mathrm{pH}$ was not significant on the response variable. Figures 7 and 8 show the Pareto diagram and the main effects on the response variable.

Table 4. ANOVA table for COD removal.

\begin{tabular}{lccccc}
\hline Source of variation & Sum of squares & GI & CM & F-ratio & P-value \\
\hline A: Current intensity (A) & 300 & 1 & 300 & 19.11 & 0.0018 \\
B: Time (min) & 1474.08 & 1 & 1474.08 & 93.89. & 0. \\
C: $\mathrm{pH}$ & 4.5 & 1 & 4.5 & 0.29 & 0.6054 \\
AA & 13.4444 & 1 & 13.4444 & 0.86 & 0.3789 \\
AB & 264.5 & 1 & 264.5 & 16.85 & 0.0027 \\
AC & 0.333333 & 1 & 0.333333 & 0.02 & 0.8874 \\
BB & 230.028 & 1 & 230.028 & 14.65 & 0.004 \\
BC & 24.0833 & 1 & 24.0833 & 1.53 & 0.2469 \\
Total error & 141.306 & 9 & 15.7006 & & \\
Total & 2452.28 & 17 & & & \\
\hline$r^{2}=94.23 \%$ & & & & &
\end{tabular}




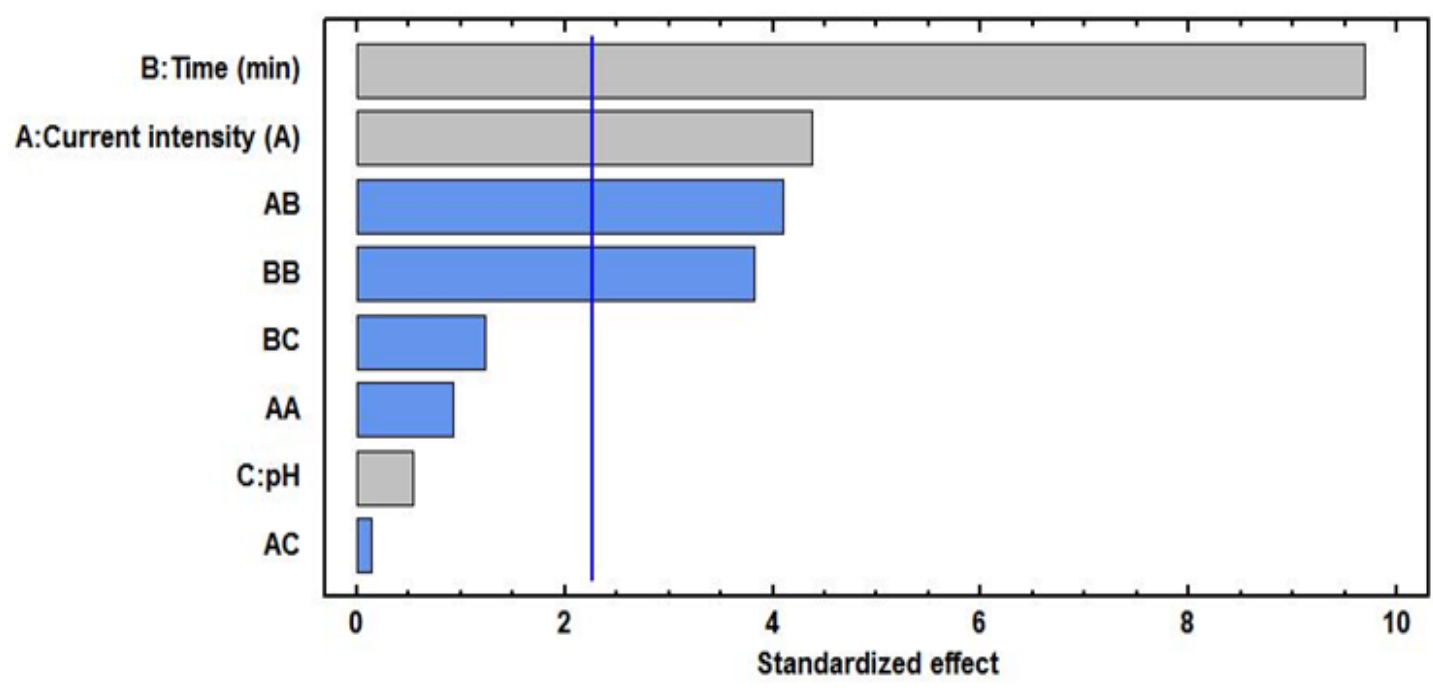

Figure 7. Standardized Pareto diagram for the removal of COD.

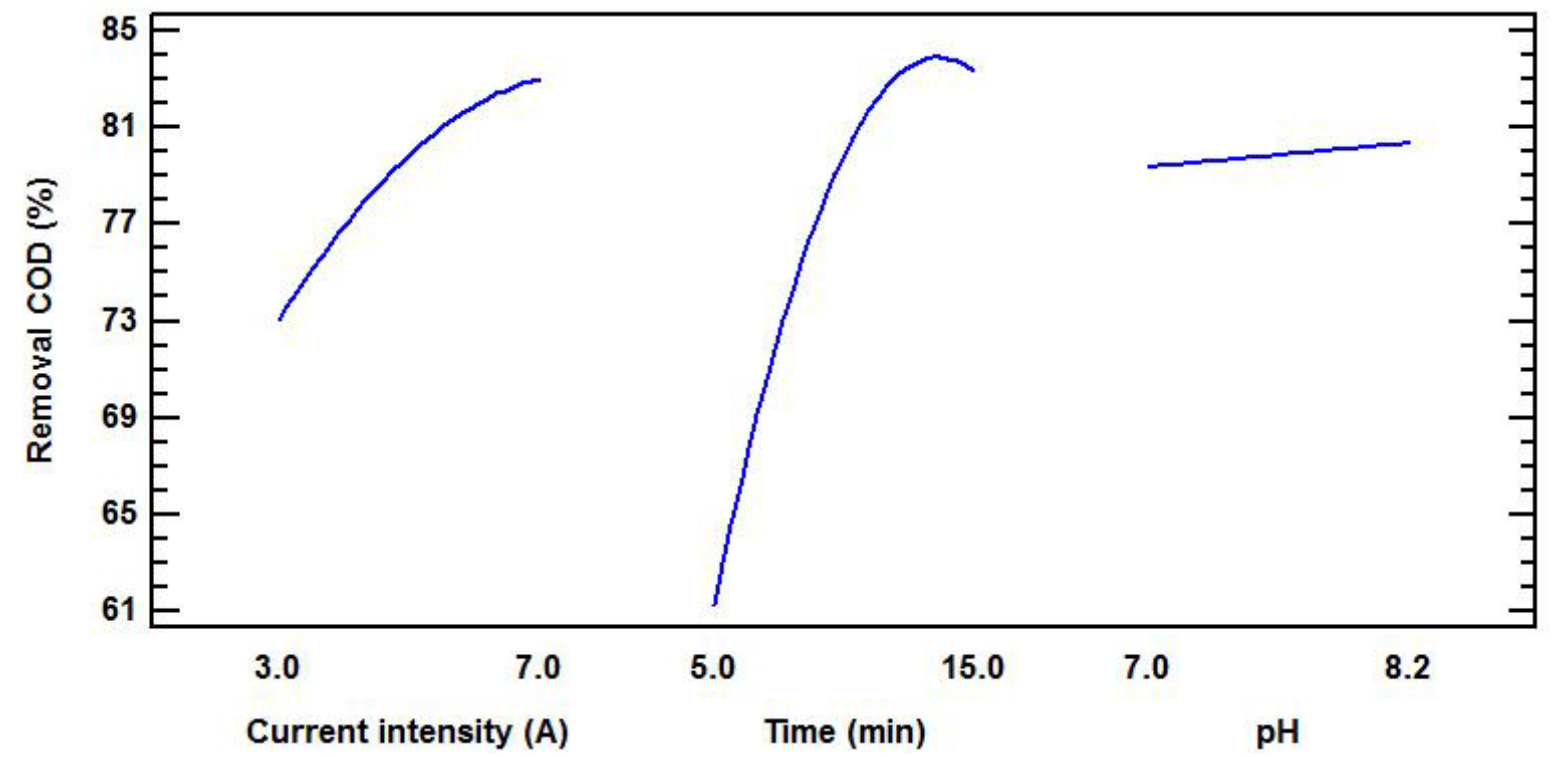

Figure 8. Graphical representation of the main effects for the removal of COD.

In addition, in Figures 9a, 9b, and 9c, the response surface graphs are presented that indicate the results of the variation of the percentage of COD removal as the current intensity, time, and $\mathrm{pH}$ conditions change, respectively. 


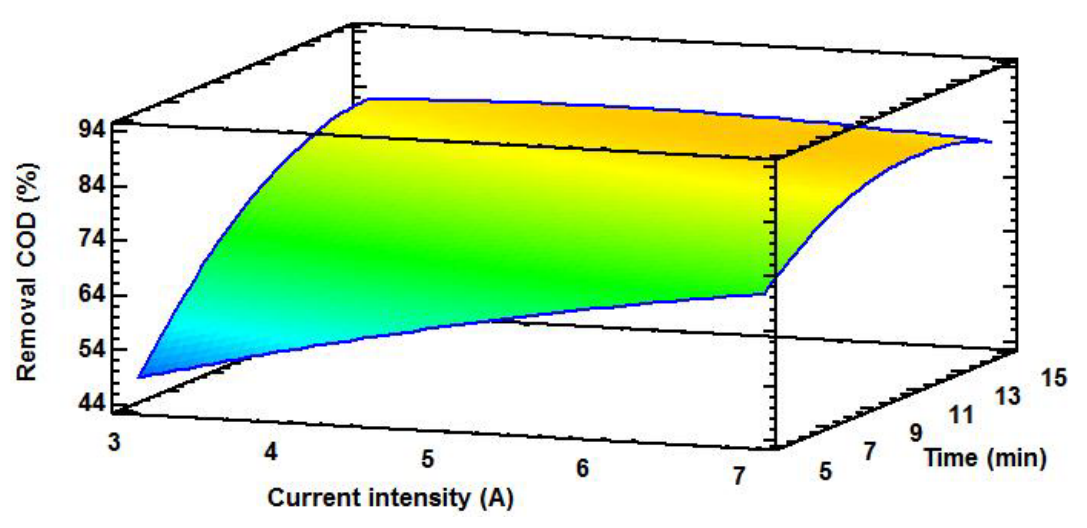

Removal COD (\%)

(9a)

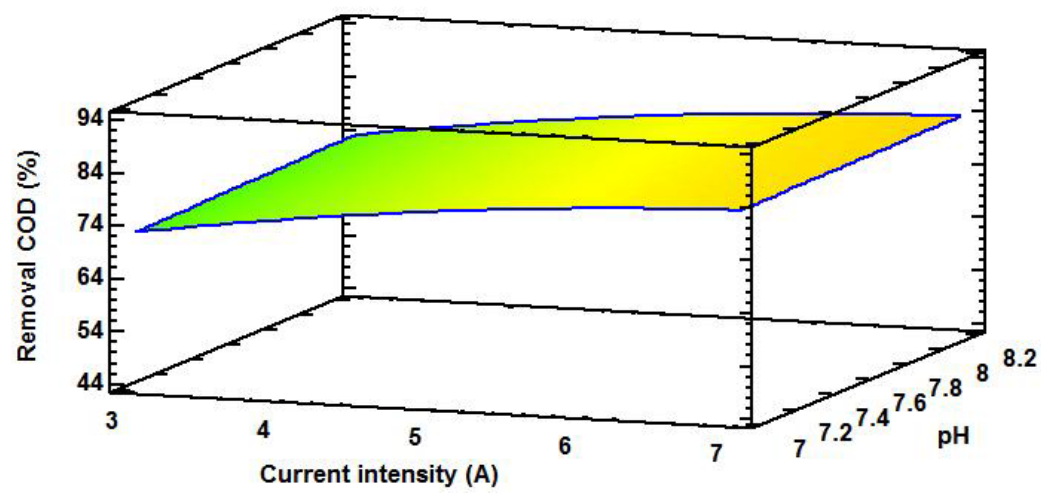

Removal COD (\%)

(9b)

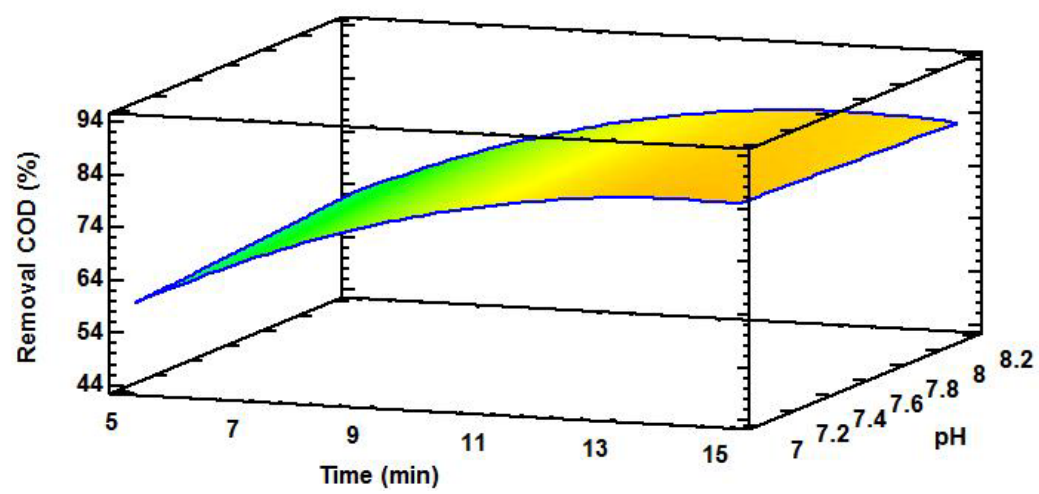

Removal COD (\%)

$\square 4.0$

$\square 49.0$

54.0

59.0

$\square 4.0$

$\square 69.0$

74.0

79.0

84.0
89.0

94.0

(9c)

Figure 9. Three-dimensional response surface graphs for the percentage of COD removal a) current and time intensity, b) current and $\mathrm{pH}$ intensity, and c) time and $\mathrm{pH}$.

\section{CONCLUSIONS}

Electrocoagulation is a viable alternative for the treatment of domestic wastewater, as it demonstrates its effectiveness in the removal of COD, and it is a more robust technology compared with biological processes. The analysis of the proposed experimental design indicates that the variable time and intensity of current were the most significant variables in the process, whereas the variable $\mathrm{pH}$ was not significant with respect to the response variable (percentage of COD removal) and had a correlation coefficient $r^{2}$ of $94.23 \%$. The best results in the percentage of removal of the COD were very similar as compared with the results at $\mathrm{pH} 7$ and 8.2 , with values of $84 \%$ and $83 \%$, respectively, with a current intensity of $7 \mathrm{~A}$ and a treatment 
time of 15 min.

Considering the treatment time, it was determined that the efficiencies obtained at $10 \mathrm{~min}$ were very similar with the three current intensities, with a minimal difference against those obtained at $15 \mathrm{~min}$. Considering the current intensity, the best removal results were obtained in the two types of $\mathrm{pH}$, at 5 and $7 \mathrm{~A}$; however, it is important to note that at an intensity of $3 \mathrm{~A}$, acceptable removal percentages were obtained that must be taken into account considering the treatment costs. The retention times being shorter than the biological processes and the compactness of the residual sludge are the other important aspects that were studied in this research. By considering the previous results, they can be considered as operational values, with a current intensity of $5 \mathrm{~A}$, a withholding time of $10 \mathrm{~min}$ and a natural $\mathrm{pH}$ of 8.2, with the goal of reducing the expense of energy and avoiding the use of reagents to lower the $\mathrm{pH}$. Another important aspect that should be noted is that the withholding times are considerably less than those observed in the biological process, which will allow us to eliminate the contaminants in short times. One of the advantages of this process is that it does not use bacteria to deteriorate the organic material, which ends up being easier to operate and maintain. Additionally, the residual mud that is generated is much more compact than biological and physiochemical mud.

\section{ACKNOWLEDGMENTS}

The authors would like to thank the Institute of Scientific Research from the University of Lima for promoting the integral development of this project and the Research Center for Wastewater Treatment and Hazardous Waste of the National University of Engineering for lending its facilities to conduct the field tests.

\section{REFERENCES}

AL-SHANNAG, M.; BANI-MELHEM, K.; AL-ANBER, Z.; AL-QODAH, Z. Enhancement of COD-Nutrients Removals and Filterability of Secondary Clarifier Municipal Wastewater Influent Using Electrocoagulation Technique. Separation Science and $\begin{array}{lllll}\text { Technology, } & \text { v. } & \text { 48,n. }\end{array}$ http://dx.doi.org/10.1080/01496395.2012.707729

AL-SHANNAG, M.; AL-QODAH, Z.; ALANANBEH, K.; BOUQELLAH, N.; ASSIREY, E.; BANI-MELHEM, K. Cod reduction of baker's yeast wastewater using batch electrocoagulation. Environmental Engineering \& Management Journal, v. 13, n. 12, p. 23153-3160, 2014.

AL-QODAH, Z.; AL-SHANNAG, M. Heavy metal ions removal from wastewater using electrocoagulation processes: a comprehensive review. Separation Science and $\begin{array}{lllll}\text { Technology, } & \text { v. } & 17, & \text { p. } & \end{array}$ http://dx.doi.org/10.1080/01496395.2017.1373677

AL-QODAH, Z.; AL-SHANNAG, M.; BANI-MELHEM, K. Free radical-assisted electrocoagulation processes for wastewater treatment. Environmental Chemistry Letters, 2018. http://dx.doi.org/10.1007/s10311-018-0711-1

BANI-MELHEM, K.; AL-SHANNAG, M.; ALROUSAN, D.; AL-KOFAHI, S.; ALQODAH, Z.; AL-KILANI, M. R. Impact of soluble COD on grey water treatment by electrocoagulation technique. Desalination and water treatment, v. 89, p. 101-110, 2017. http://dx.doi.org/10.5004/dwt.2017.21379 
BAZRAFSHAN, E.; KORD MOSTAFAPOUR, F.; FARZADKIA, M.; OWNAGH, K. A.; MAHVI, A. H. Slaughterhouse Wastewater Treatment by Combined Chemical Coagulation and Electrocoagulation Process. PLOS ONE, v. 7, p. 40108, 2012. http://dx.doi.org/10.1371/journal.pone.0040108

BAZRAFSHAN, E.; MOSTAFAPOUR, F. K.; SOORI, M. M.; MAHVI, A. H. Application of combined chemical coagulation and electrocoagulation process to carwash wastewater treatment. Fresenius Environmental Bulletin, v. 21, n. 9a, p. 2694-2701, 2012.

BAZRAFSHAN, E.; MOEIN, H.; KORD MOSTAFAPOUR, F.; NAKHAIE, S. Application of Electrocoagulation Process for Dairy Wastewater Treatment. Journal of Chemistry, v. 2013, p. 1-8, 2013. http://dx.doi.org/10.1155/2013/640139

BAZRAFSHAN, E.; ALIPOUR, M. R.; MAHVI, A. Textile wastewater treatment by application of combined chemical coagulation, electrocoagulation, and adsorption processes. Desalination and Water Treatment, v. 57, p. 9203-9215, 2015. http://dx.doi.org/10.1080/19443994.2015.1027960

CHEN, G. Electrochemical technologies in wastewater treatment. Separation and $\begin{array}{llllll}\text { Purification } & \text { Technology, } & \text { v. } & \text { 38, } & \text { p. } & \text { 11-41. }\end{array}$ http://dx.doi.org/10.1016/j.seppur.2003.10.006

HOLT, P.; BARTON, G.; MITCHELL, C. The future for electrocoagulation as a localized water treatment technology. Chemosphere, v. 59, p. 355-367, 2005. http://dx.doi.org/10.1016/j.chemosphere.2004.10.023

KARICHAPPAN, T.; VENKATACHALAM, S.; JEGANATHAN, P. M. Optimization of electrocoagulation process to treat grey wastewater in batch mode using response surface methodology. Journal of Environmental Health Science and Engineering, v. 12, p. 18, 2014. http://dx.doi.org/10.1186/2052-336X-12-29

KOBYA, M.; DEMIRBAS, E.; CAN, O.; BAYRAMOGLU, M. Treatment of levafix orange textile dye solution by electrocoagulation. Journal of Hazardous Materials, v. 132, p. 183-188, 2006. http://dx.doi.org/10.1016/j.jhazmat.2005.07.084

KUOKKANEN, V.; KUOKKANEN, T.; RAMO, J.; LASSI, U. Recent Applications of Electrocoagulation in Treatment of Water and Wastewater-A Review. Green and Sustainable Chemistry, v. 3, p. 89-121, 2013. http://dx.doi.org/10.4236/gsc.2013.32013

KURT, U.; GONULLU, M. T.; ILHAN, F.; VARINCA, K. Treatment of domestic wastewater by electrocoagulation in a cell with Fe-Fe electrodes. Environmental Engineering Science, v. 25, n. 2, p. 153-160, 2008. http://dx.doi.org/10.1089/ees.2006.0132

MANSOORIAN, H. J.; RAJABIZADEH, A.; BAZRAFSHAN, E.; MAHVI, A. H. Practical assessment of electrocoagulation process in removing nickel metal from aqueous solutions using iron-rod electrodes. Desalination and Water Treatment, v. 44, p. 2935, 2012. https://dx.doi.org/10.1080/19443994.2012.691708

MERZOUK, B.; GOURICH, B.; SEKKI, A.; MADANI, K. CHIBADNE, M. Removal turbidity and separation of heavy metals using electrocoagulation- electroflotation technique. A case study. Journal of hazardous materials, v. 164, p. 215-222, 2009. http://dx.doi.org/10.1016/j.jhazmat.2008.07.144 
MOLLAH, M.; MORKOVSKY, P.; GOMES, J.; KESMEZ, M.; PARGA, J.; COCKE, Fundamentals, present and future perspectives of electrocoagulation. Journal of Hazardous Materials, v. 114, p. 2004. https://dx.doi.org/10.1016/j.jhazmat.2004.08.009

MORENO, H.; PARGA, J.; GOMES, A.; RODRÍGUEZ, M. Electrocoagulation treatment of municipal wastewater in Torreon Mexico. Desalination and Water Treatment, v. 51, p. 2710-2717, 2013. https://dx.doi.org/10.1080/19443994.2012.749366

OZYONAR, F.; KARAGOZOGLU, B. Operating Cost Analysis and Treatment of Domestic Wastewater by Electrocoagulation using Aluminium Electrodes. Polish Journal of Environmental Studies, v. 20, p. 173-199, 2011.

PIÑA, M.; MARTÍN, A.; GONZÁLEZ, C.; PRIETO, F.; GUEVARA, A.; GARCÍA, Revisión de variables de diseño y condiciones de operación en la electrocoagulación. Revista Mexicana de Ingeniería Química, v. 10, n. 2, p. 257-271, 2011.

RESTREPO, A.; ARANGO, A.; GARCÉS, L. La Electrocoagulación: retos y oportunidades en el tratamiento de aguas. Producción + Limpia, v. 1, n. 2, p. 58-77. 2006.

SARALA, C. Domestic Wastewater Treatment by Electrocoagulation with Fe-Fe Electrodes. International Journal of Engineering Trends and Technology, v. 3, p. 530-533, 2012.

SMOCZYŃSKIA, L.; KALINOWSKIA, S.; RATNAWEERAB, H.; KOSOBUCKAA, M.; TRIFESCUA, M.; SMOCZYŃSKAA, K. P. Electrocoagulation of municipal wastewater - a pilot-scale test. Desalination and Water Treatment, v. 72, p. 162-168, 2017. http://dx.doi.org/10.5004/dwt.2017.20645 